Дмитренко Т. Р.,

студентка,

лаборант кафедри бібліотекознавства та інформології, Інститут журналістики

Київського університету імені Бориса Грінченка, (Київ, Україна)

Ел. пошта: trdmytrenko.ij16@kubg.edu.ua
Tetiana Dmytrenko,

student, laboratory assistant of

Library Science and Informology,

Institute of Journalism

of Borys Grinchenko Kyiv University,

(Kyiv, Ukraine)

Email: trdmytrenko.ij16@kubg.edu.ua

ЧУКАНОВА С. О.

БІБЛІОТЕКОЗНАВСТВО ТА ІНФОРМОЛОГІЯ У СИСТЕМІ ВИЩОЇ ОСВІТИ США: МОНОГРАФІЯ. ПОКАЖЧИК ЗМІСТУ

\title{
CHUKANOVA S. O. LIBRARY SCIENCE AND INFORMATION SCIENCE IN THE US HIGHER EDUCATION SYSTEM: MONOGRAPH. INDEX OF CONTENTS
}

Анотачія. В монографії розглянуто організачійно-методичні засади професійної підготовки фахівців із бібліотекознавства та інформологї у системі вищої освіти СШІА: структуру та зміст, форми організації, спрямованість професійної підготовки на забезпечення професійної мобільності цих фахівців.

Визначено та обгрунтовано напрями використання досвіду США у модернізачї професійної підготовки фахівців інформаційної, бібліотечної та архівної справи в Украӥні.

Ключові слова: Чуканова С. О., «Бібліотекознавство та інформологія у системі вищої освіти США», монографія.

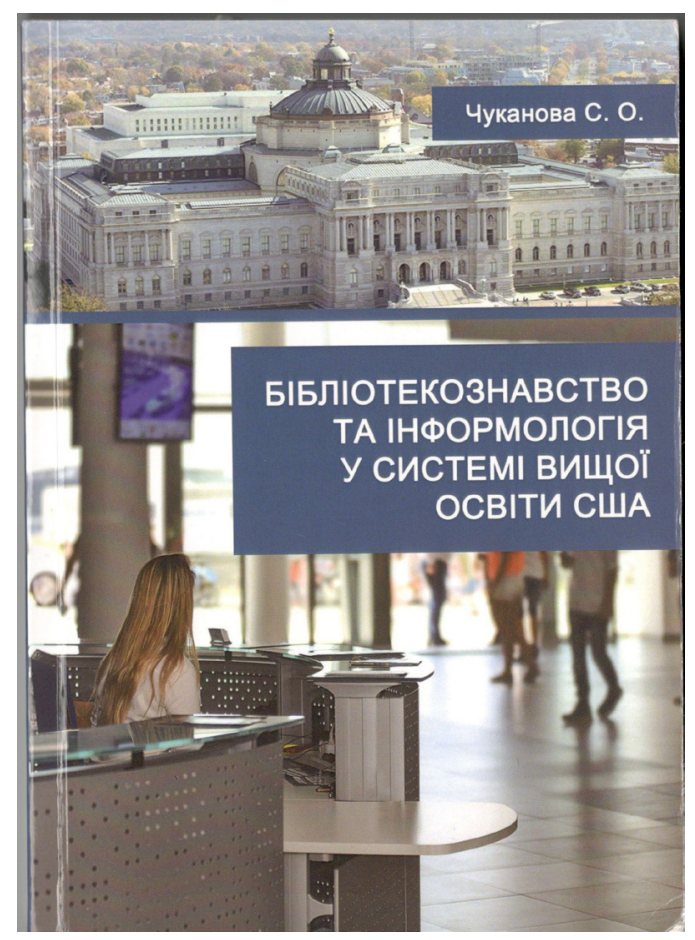

ISSN $2524-2644$
Abstract. The monograph discusses the organizational and methodological foundations of the professional training of specialists in library science and informology in the US higher education system: structure and content, forms of organization, orientation of professional training to ensure the professional mobility of these specialists.

The directions of using the US experience in modernization of professional training of specialists of information, library and archives in Ukraine are defined and substantiated.

Keywords: Chukanova S. O., «Library Science and Information Science in the US Higher Education System», monograph.

Б ібліографоване джерело: Чуканова С. О. Бібліотекознавство та інформологія у системі вищої освіти США : монографія / С. О. Чуканова. Київ : Аграр Медіа Груп, 2018. - 286 с.

Зміст монографії: Вступ, 4-13 ; Розділ 1. Минуле та сучасне професійної підготовки фахівців із бібліотекознавства та інформології у США, 14-81 : 1.1. Базові поняття професійної підготовки бібліотекознавців та інформологів у США, 14-30; 1.2. Історико-педагогічний аналіз розвитку та реформування бібліотечно-інформаційної освіти у США, 30-60; 1.3. Відображення проблеми професійної підготов-

(C) Дмитренко Т. Р., 2019

Integrated communications, 1 (7), 2019 
ки фахівців із бібліотекознавства та інформології у педагогічній теорії, 60-81 ; Розділ 2. Принципи організації професійної підготовки фахівців із бібліотекознавства та інформології у США, 82-155 : 2.1. Структура і зміст бібліотечно-інформаційної освіти у США, 82-117; 2.2. Організаційні форми професійної підготовки фахівців із бібліотекознавства та інформології у США, 117-132; 2.3. Професійна мобільність бібліотечно-інформаційних фахівців у США, 132-145; 2.4. Тенденції сучасної професійної підготовки фахівців із бібліотекознавства та інформології у США, 145-155 ; Розділ 3. Значення досвіду професійної підготовки фахівців із бібліотекознавства та інформології у США для України, 156-202 : 3.1. Стан професійної підготовки фахівців із інформаційної, бібліотечної та архівної справи в Україні, 156-167; 3.2. Порівняння професійної підготовки фахівців із бібліотекознавства в США і Україні, 167-187; 3.3. Модернізація професійної підготовки фахівців з інформаційної, бібліотечної та архівної справи в Україні з використанням досвіду США, 187-202 ; Післямова, 203-207 ; Перелік умовних скорочень, 208-209 ; Список використаних джерел, 210-244 ; Додатки, 245-286 : Додаток 1, Зміст МП із бібліотекознавства та інформології у ВНЗ США станом на 1989 рік, 245-247 ; Додаток 2, «Стандарти Американської бібліотечної асоціації з акредитації магістерських програм із бібліотекознавства та інформології» у редакції від 15 січня 2008 року, 248-252 ; Додаток 3, Стандарти Американської бібліотечної асоціації 3 акредитації магістерським програм із бібліотекознавства та інформології у редакції від 02 лютого 2015 року (переклад), 253-264 ; Додаток 4, Вступ до бібліотекознавства та інформології Навчальний план магістерської програми на 2010 рік (витяг) бібліотечної школи Університету Святої Катерини (St. Catherine university), 265-268 ; Додаток 5, Витяг з нашого проекту робочої програми навчальної дисципліни «Бібліотекознавство та інормологія» напрям підготовки 6.020102 «Книгознавство, бібліотекознавство і бібліографія» ОКР 6.020102 бакалавр спеціалізація «Книгознавець-бібліотекознавець, менеджер бібліотечно-інформаційної діяльності», 269-280 ; Додаток 6, Словник іншомовних понять і термінів, 281-286.

\section{Бібліографоване джерело}

1. Чуканова С. О. Бібліотекознавство та інформологія у системі вищої освіти США : монографія. Київ : Ahrar Media Hrup, 2018. 286 c.

\section{Reference}

1. Chukanova, S. O. (2018), «Library Science and Information Science in the US Higher Education System», monograph, Kyiv: Ahrar Media Hrup, 436 p.

Подано до редакиї 12.03. 2019 р.

Дмитренко Т. Р., студентка,

лаборант кафедры библиотековедения и информологии,

Институт журналистики

Киевского университета имени Бориса Гринченко

(Киев, Украина)

\title{
ЧУКАНОВА С. А. \\ БИБЛИОТЕКОВЕДЕНИЯ И ИНФОРМОЛОГИЯ В СИСТЕМЕ ВЫСШЕГО ОБРАЗОВАНИЯ США: МОНОГРАФИЯ. УКАЗАТЕЛЬ СОДЕРЖАНИЯ
}

\begin{abstract}
Аннотация. В монографии рассмотрены организачионно-методические основы профессиональной подготовки специалистов по библиотековедению и информологии в системе высшего образования США: структура и содержание, формы организации, направленность профессиональной подготовки на обеспечение профессиональной мобильности этих специалистов.

Определены и обоснованы направления использования опыта США в модернизащии профессиональной подготовки спечиалистов информачионного, библиотечного и архивного дела в Украине.

Ключевые слова: Чуканова С. А., «Бібліотекознавство та інформологія у системі вищої освіти США», монография.
\end{abstract}

